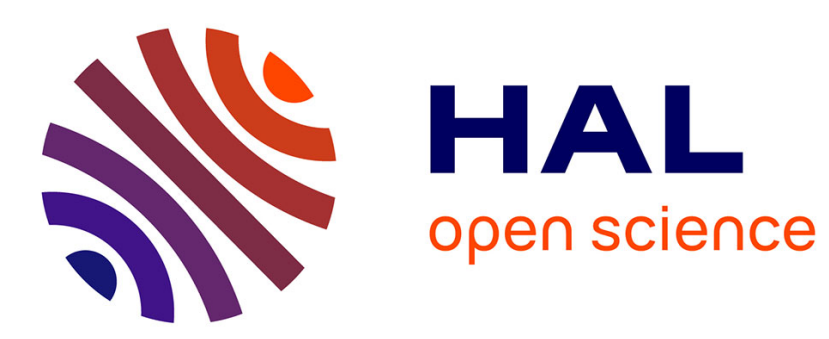

\title{
The Outcome of NGOs' Activism in Developing Countries under Visibility Constraint
}

Lionel Fontagné, Michela Limardi

\section{To cite this version:}

Lionel Fontagné, Michela Limardi. The Outcome of NGOs' Activism in Developing Countries under Visibility Constraint. 2011. halshs-00630096v2

\section{HAL Id: halshs-00630096 \\ https://shs.hal.science/halshs-00630096v2}

Preprint submitted on 24 Nov 2011

HAL is a multi-disciplinary open access archive for the deposit and dissemination of scientific research documents, whether they are published or not. The documents may come from teaching and research institutions in France or abroad, or from public or private research centers.
L'archive ouverte pluridisciplinaire HAL, est destinée au dépôt et à la diffusion de documents scientifiques de niveau recherche, publiés ou non, émanant des établissements d'enseignement et de recherche français ou étrangers, des laboratoires publics ou privés. 


\section{PARISSCHOQL OF ECONOMICS}

WORKING PAPER N² 2011 - 35

The Outcome of NGOs' Activism in Developing Countries under Visibility Constraint

Lionel Fontagné

Michela Limardi

JEL Codes: J51, J80

Keywords: Labour standards, NGOs, Wage determination

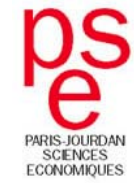




\title{
The Outcome of NGO Activism in Developing Countries under Visibility Constraint*
}

\author{
Lionel Fontagnéł Michela Limardi ${ }^{\ddagger}$
}

November 23, 2011

\begin{abstract}
Many developing countries ratified the International Labor Organization's Fundamental Conventions and authorized local labor unions. Multinational companies producing in these countries pay more in response to NGO campaigns and when reputation counts. However, whether NGOs' actions benefit local workers beyond those employed in MNE affiliates in host countries is an open issue. We develop a bargaining model adapted to the peculiarities of labor market institutions in developing countries, i.e. external funding from the North and complementarity of labor unions and domestic labor NGOs. This model is estimated on data for Indonesian manufacturing firms, before and after the authorization of labor unions, in sectors sensitive or not to external pressure, in the presence or not of labor NGOs. We find that, in sensitive sectors, wages increase less in presence of NGOs. External funding implies a distortion in the objectives of labor unions, confronted with the constraint of increasing employment in the formal sector.
\end{abstract}

Keywords: labor standards, NGOs, wage determination

JEL: J51, J80

\footnotetext{
${ }^{*}$ We thank Tito Boeri and participants at the ETSG Conference (Lausanne) for their comments; we acknowledge the advice of Margherita Comola on the data

${ }^{\dagger}$ Paris School of Economics (University Paris 1) and CEPII, email: lionel.fontagne@univ-paris1.fr

${ }^{\ddagger}$ PSE-Paris School of Economics and University of Bologna, email: michela.limardi@gmail.com
} 


\section{Introduction}

With the spread of globalization, two major actors have emerged and developed: Multinational Enterprises (MNEs) and their network of subcontractors (Antras \& Helpman, 2004), and international Non-Governmental Organizations (NGOs) (Aldashev \& Verdier, 2009). The two interact with each other through the increasing level of monitoring carried out by international NGOs. Civil society and international NGOs accuse MNEs of not applying labor standards in their affiliates in Developing Countries (DCs). Recent studies show that MNEs pay more in response to NGO campaigns and when reputation counts (Harrison \& Scorse, 2010). However, whether this external pressure from NGOs benefits local workers outside MNEs affiliates in host countries is unclear.

Due to reputation effect, DCs have shifted towards more labor protection (Caraway, 2004). Over a hundred DCs ratified the International Labor Organization's (ILO) Fundamental Conventions, improved domestic labor laws, and authorized local labor unions. ${ }^{1}$ However, despite this reshaped regulatory environment, there is still evidence that sweatshops have not been eradicated. Two factors may explain this. First, many DCs are characterized by weak enforcement institutions (Boeri et al., 2008). Second, in countries where labor unions were formerly banned, local labor unions face financial constraints and suffer from lack of expertise in collective bargaining. The role of weak enforcement institutions has been well documented (Bigsten et al., 2003; Martins \& Esteves, 2007). We focus here on the complex relation between NGOs from the North, labor unions in the South, and labor NGOs in the South. This is where financing, training, and advice offered by NGOs to labor unions, matters.

In several DCs, with poor workers, labor unions have to rely on financing from NGOs in the North, and whether or not they receive financial aid depends, to a large extent, on labor union visibility. At the same time, Northern NGOs rely on public or private financing. Therefore, Northern NGOs are more inclined to finance labor unions and local labor NGOs operating in "sensitive" sectors, in order to satisfy political demands. ${ }^{2}$ Thus, higher labor union visibility carries a premium in sectors targeted by Northern donors.

\footnotetext{
${ }^{1}$ http://www.ilo.org/ilolex/english/docs/declworld.htm.

${ }^{2}$ Responsible consumers care about the conditions of workers in poor countries. Political authority and labor unions in the North might support labor unions in the South in order to raise the level of labor standards and reduce the competitiveness of these countries. The impact of this kind of indirect trade policy measure on labor markets in DCs is an important issue for analysis.
} 
Labor intensive activities are at the top of the list of the sectors targeted by Northern NGOs. For instance, in 2006, the Dutch Clean Clothes Campaign ${ }^{3}$ conducted a joint campaign called True Blue, with Amnesty International, the Fair Wear Foundation, and Goede Waar and Co. (a consumer organization) with the aim of raising awareness about working conditions in the Chinese garment industry. According to the General Secretary of the Indonesian Federation of Independent Trade Unions, the Clean Clothes Campaign enabled them "to join with workers and activists around the world" so they did not have to face "their struggle alone". ${ }^{4}$

Most outside financing of Southern labor unions comes from specialized NGOs. The main donors are international trade unions, such as the International Trade Union Confederation (ITUC), and trade union solidarity organizations, such as the American Center for International Labor Solidarity (ACILS). ${ }^{5}$ For instance, in 2005, ACILS gave USD 156,624 to support the unions' internal democratic mechanisms and the ability of trade unions to organize and represent workers in the Latin American region (Paraguay, Argentina, Uruguay, Chile, Brazil). In 2008-09, Union Aid Abroad-APHEDA sent USD 10,000 to the Philippines trade union federation, the Kilusang Mayo Uno (KMU), to provide organizers' training courses. ${ }^{6}$

Another pattern among the labor markets institutions in developing countries is the complementarity between labor unions and local NGOs working on labor issues. Local labor unions and local NGOs cooperate, in various regions of the world, including Southeast Asia. In Thailand, trade unions and NGOs campaigned jointly for improvements to occupational health and safety after a fire in a toy factory killed 188 people in May 1993; they subsequently developed new alliances (Brown, 2004). In Malaysia, women's NGOs and the women's section of the Malaysian Trade Union Congress have worked together on many issues (Crinis, 2008). A Jakarta-based,

\footnotetext{
${ }^{3}$ The Clean Clothes Campaign (CCC) is an international network that comprises a wide variety of organizations, such as trade unions, consumer organizations, researchers, solidarity groups, women's organizations, church groups, youth movements, and world shops. The aim is to improve working conditions in the global garment industry and to empower workers, most of whom are women, "with the ultimate goal of ending the oppression, exploitation and abuse in this sector".

${ }^{4}$ Emelia Ianti Mala Dewi Sihaan, CCC website.

${ }^{5}$ The ITUC Solidarity Fund gives assistance for trade union action in countries where it is most needed. It helps organizations and individuals facing hardship or repression, and supports trade union campaigns, organizing and strengthening capacities and structures. Oversight and management of the Fund is the responsibility of the Solidarity Fund Management Board. In 2010, the Fund supported activities to a total of 1 million euros. The Fund is financed by voluntary contributions from ITUC affiliates. ACILS is a non-profit US organization financed $96 \%$ by the US government.

${ }^{6}$ APHEDA is the overseas humanitarian aid agency of the Australian Council of Trade Unions (ACTU). The agency, was established by the ACTU in 1984 to enable Australian workers, through their unions, to provide direct assistance for international development by supporting projects for workers in developing countries.
} 
grassroots NGO activist reports that "the task of NGOs is to encourage workers to form unions, not to control them. NGOs have to raise their self-awareness so that they see the need to organize" (Ford, 2005). While several DCs have recently authorized labor unions, many lack experience in collective bargaining. In these cases, local labor NGOs provide technical and legal assistance to workers, and disseminate information on domestic labor laws and workers' rights.

Therefore, the presence of local labor NGOs is expected to change the outcome of collective bargaining in countries with no culture of negotiation. It is this outcome that is of interest. We would point out, however, that not all workers are employed in affiliates of foreign companies; and, among workers employed outside these affiliates, not all workers are employed in the formal sector where labor unions are active.

While the literature so far has focused on the impact of NGO activism on labor conditions in multinational affiliates, in this paper we focus on domestic firms to analyze the role of domestic labor NGOs supporting local labor unions, for workers outside MNE affiliates. Focusing on domestic firms implies that reputation is no longer relevant. Domestic firms are not concerned about maintaining reputation as they do not export, at least not directly. This is the first difference with the existing literature. The second is that the present study explicitly addresses the consequences of the dual nature of the labor market in DCs, where the informal sector offers a convenient way of bypassing labor laws. In this study, workers' outside option is the wage paid in the formal sectors and the informal sector, and the assistance provided by domestic NGOs. ${ }^{7}$

The purpose of this paper is to investigate the interaction between the presence of NGOs and the "visibility premium" of a labor union, and their impact on the bargaining power of workers. We develop a bargaining model to study the interaction between the visibility premium, bargaining power, and outside option of workers, in the determination of individual wages in DCs. As already mentioned, in poor countries local labor unions (where they exist) face financial constraints. They rely on external funding from the North. Northern donations are focused on the largest Southern labour unions (Ford, 2009). But the advantage of large size is limited to unions active in sensitive sectors (as defined above). This visibility constraint implies a distortion in the traditional labor union objective (i.e. higher wages). Labor unions also want to increase their visibility and, thus, the number of workers in the formal sector, where there is more respect for labor rights. We

\footnotetext{
${ }^{7}$ See Section 2 for more details on the outside option of workers.
} 
formalize the complementarity between local labor NGOs and local labor unions: local labor NGOs affect the outside option of workers by increasing the available information on labor rights. ${ }^{8}$

Our two main theoretical predictions are as follows. Wages increase with the presence of labor NGOs. However, wages decrease with the visibility premium in sensitive sector. The argument is that local labor unions have contradictory objectives in "sensitive" sectors: increasing their own visibility, alongside the traditional higher wages objective. To test these predictions, we need data on domestic manufacturing firms in a developing country, belonging or not to sensitive sectors, before and after authorization of labor unions, in the presence or not of local labor NGOs.

The case of Indonesia offers this combination and is used to validate the following predictions. Local labor NGOs have played an important role in the Indonesian working-class movement. The post-Suharto era has been defined by a strong complementarity between local labor unions and local labor NGOs. Ford (2005) explains how Indonesia's labor NGOs are part of a global surge in non-traditional labor activism, in which international and indigenous labor NGOs are playing an important role. Most local NGOs and labor unions are financed by foreign NGOs. These donations are project or time based. Over recent years, Northern NGOs have focused on workers condition in labor intensive sectors in Indonesia, such as textiles, footwear, and apparel. ${ }^{9}$ We rely on Data on the Indonesia Manufacturing Industry for the period 1991-2005, a period that covers the Trade Union Act of 2000, which authorized independent labor unions. ${ }^{10}$ We exploit a difference-indifference-in-difference method. We study the external shocks (before and after the labor law), the role of complementarity between labor NGOs and labor unions (provinces with/without labor NGOs), and the visibility premium (textiles versus other sectors).

Our theoretical predictions are validated in the Indonesian manufacturing case. Wages are higher in provinces with labor NGOs with respect to provinces without labor NGOs. Therefore, the complementarity between labor NGOs and labor unions has a positive impact on wages. The presence of NGOs gives power to labor unions (it increases the outside option of workers). However, in sectors on the radars of Northern NGOs, labor unions have the objective also of increasing the number of members employed in the formal sector, i.e. increasing their visibility. We find that,

\footnotetext{
${ }^{8}$ Indeed, firms might avoid compliance with labor standards due to weak enforcement institutions and corruption. This is not central however to our demonstration and has been documented extensively elsewhere. More importantly, employers can resort to the informal sector.

${ }^{9}$ For more detail on this issue see section 3.1.

${ }^{10}$ During the Suharto Regime there was only one labor union officially recognized by government. The Trade Union Act of 2000 permitted groups of 10 or more workers to form a union at firm level.
} 
in sensitive sectors, wages increase less in presence of NGOs.

The remainder of the paper is organized as follows: Section 2 presents the bargaining model, Section 3 presents the empirical analysis based on the manufacturing industry in Indonesia, Section 4 concludes.

\section{Bargaining Model}

In Indonesia, following the Trade Union Act of 2000, all issues specific to wages and employment are bargained at the enterprize level: the regional and national levels have no influence. ${ }^{11}$ This institutional context is the motivation for our choosing to analyze wage determinations at firm level. We rely on the rent-sharing literature (Hildreth and Oswald, 1997; Dobbelaere, 2004; Martins and Esteves, 2006). More specifically, we rely on an efficient bargaining model where firms and unions bargain over wage and employment (Blanchflower et al., 1996). This model predicts a positive relation between profit and wage if the labor union has some bargaining power.

Wages are determined as in a Nash problem in which $0 \leq \phi \leq 1$ represents the workers bargaining power. The maximization problem is as follows:

$$
[w n+a n-u(\bar{w}) n]^{\phi}\left[\pi^{1-\phi}\right]
$$

where $w$ represents the wage if bargaining succeeds and $\bar{w}$ is the outside earnings of workers were they not employed by the firm; $a \geq 0$ represents the visibility premium of the labor union; $n$ indicates the employment level and $\pi$ denotes profit.

The outside option of workers can be described by the function:

$$
\bar{w}=f\left(w^{o}, b, I, \tau\right)
$$

where $w^{o}$ is the alternative wage in other sectors, $b$ the wage in the informal sector, $I$ the informality rate and $\tau$ the presence of a labor NGO, i.e. a NGO working on labor issues.

\footnotetext{
${ }^{11}$ Collective bargaining in Indonesia, ILO- Japan Multi- Lateral Project, 2006.
} 
The utility of unionized non-employed workers (i.e. the member reservation utility) used in the Nash bargaining model is fairly standard in the rent-sharing literature (Blanchflower et al, 1996). We adapt this idea to account for the features of the labor market institutions in Indonesia.

In Indonesia, one of the problems in delivering the right of freedom of association and collective bargaining is lack of understanding of the basic laws and procedures relating to collective bargaining and labor relations (ILO, 2006). Labor NGOs have been important players on labor rights issues (Ford, 2003) and NGOs activity has had an impact on labor market outcomes. Thus, we assume that NGO activity increases the outside option of workers by providing more information on labor rights and job opportunities. Because reputation is not an issue for domestic firms, the threat of local NGO activity is not credible for those firms. The available and credible instrument is NGO advocacy activity aimed at informing workers about their rights. Also, the majority of the workforce is employed in the informal sector. ${ }^{12}$ Due to lack of social security and the high rate of informal labor, we consider the informal sector and wages rather than the unemployment rate and benefits more generally used in the literature.

The interpretation of this outside option is that $\bar{w}$ is the expected income and $I$ determines the probability of receiving $b$ instead of $w^{\circ}$ (Blanchflower et al, 1996).

By solving the maximisation problem and after substitution we get the wage equation:

$$
w^{*}=f\left(w^{o}, b, \tau\right)+\frac{\phi}{1-\phi} \frac{\pi}{n}-a
$$

Lemma 1: Under bargaining, the equilibrium wage is a decreasing function of the visibility premium $(a \geq 0)$ of the labor union; an increasing function of the profit per employee; and an increasing function of workers' outside option.

The intuition is that local labor unions have two objectives which are contradictory: to increase their visibility and to win higher wages for workers. Visibility is represented by the number of members employed in the formal sector. Higher visibility implies more donor funding since

\footnotetext{
${ }^{12}$ In 2004 almost $70 \%$ of workers were employed in traditional jobs in the informal sector. See Indonesia's Urban Studies, http://indonesiaurbanstudies.blogspot.com/2007/05/urban-planning-and-informal-sector-in.html
} 
Northern donations target bigger unions with higher probabilities of successful bargaining for better worker conditions at firm level in sensitive sectors. In the present analysis, other assumptions about external funding mechanisms are not necessary. Visibility earns a premium $a>0$ in sectors where donors' (i.e. consumers' and policy makers') interest in the North is higher. In Indonesia, following the Trade Union Act of 2000, Northern donations targeted the footwear, textiles, and garment sectors. Therefore, due to the high level of competition among them, labor unions will bargain over employment in order to increase their visibility. In sectors targeted by Northern donations in Indonesia, the collection of dues is not an issue for the local labor union. Therefore, the employers can internalize this effect of size on the bargaining position of unions since this might occur through lower wages.

In the empirical analysis we test our theoretical predictions. We want to analyze the role of the complementarity between local labor unions, acting in sensitive sectors, and domestic NGOs. Note that our model is a partial equilibrium analysis, where the environment outside the representative firm is assumed to be the same whatever bargaining outcome is achieved. The results from a general equilibrium framework might be different.

\section{Empirical Analysis}

\subsection{Background}

Indonesia is an ideal case for our theoretical settings, due to the variability over time in labor market relations. President Suharto's resignation in May 1998 radically changed Indonesia's industrial relations landscape. ${ }^{13}$ The new government ratified eight ILO Conventions; one of them was Convention N. 87 on the "Freedom of Association and the Protection on the Right to Organize". During the Suharto Regime only one labor union was officially recognized by government and independent labor unions were banned and any activities severely repressed. The Trade Union Act of 2000 permitted groups of 10 or more workers to form a union at firm or national level. ${ }^{14}$ By August 2000, 24 national union organizations and over 10,000 enterprize unions had been registered with the Department of Manpower. There are federations and confederations of labor unions

\footnotetext{
${ }^{13}$ Suharto was the second president of Indonesia and held office from 1967 to 1998.

${ }^{14}$ Two other important labor laws were passed in these years. The Manpower Act (Law n.13/2003) and Law 2001 on minimum wages. The Manpower Act defines the rules for the right to strike; Law 2001 transferred the right to set the minimum wage from central to local (at province level) government.
} 
but enterprise unions are considered the most important due to their direct relationships with both workers and management. A Collective Labor Agreement (CLA) shall be made between one (or several) registered trade unions and an employer. An alternative system used by firms is the Company Regulation requiring the agreement of a labor union. ${ }^{15}$ According to the ILO Survey on Collective Bargaining in Indonesia (2006): "the frequent failure of labor unions to secure CLA at the enterprize level results from a lack understanding of the concepts of collective bargaining, poor negotiation skills of the parties and inadequate preparations." (p.20) Therefore, technical and legal support for labor NGOs must affect the role of weak labor unions. ${ }^{16}$

Caraway (2004) argues that labor union success in the immediate post-Suharto years can be explained by international pressure to restore basic labor rights and early remobilization of labor. However, despite this reshaped regulatory environment, the impact of labor unions is limited because of weak enforcement institutions, and because of the features of the local labor market, in particular the lack of a tradition of labor market negotiation. ${ }^{17}$ In the absence of free labor unions, the last period of the Suharto regime was characterized by radical and violent activity. Despite the passing of the Trade Union Act in 2000, lack of expertise on collective bargaining and technical skills reduced the impact of independent labor unions on workers' conditions. To some extent, this lack of expertise has been compensated for by the activities of local labor NGOs. These NGOs play important roles in Indonesia society and particularly in the working-class movement. Pro-labor NGOs provide important services to workers and labor organizations. They offer legal advice and legal services, training in labor law, and assistance to workers arrested and /or imprisoned. NGOs are the most important source of support to workers (Botz, 2001). To summarize, cooperation with labor NGOs is important to rebuild the negotiating capacity of labor unions. Most local labor unions rely heavily on international donors for funding. Most outside financing comes from Northern NGOs such as ACILS, a non-profit US organization, NOVIB-Oxfam (Dutch), Friedrich Ebert Stiftung (German) and APHEDA (Australia), Ford (2005). ${ }^{18}$

\footnotetext{
${ }^{15} \mathrm{CLA}$ and company regulation are almost the same since both tend to adhere to the legal minima (Julia \& Putranto. 2006).

${ }^{10}$ Note that the Department of Manpower can still withdraw official recognition of a union that does not meet administrative requirements, and the courts can dissolve unions whose leaders are deemed to "threaten national security".

${ }^{17}$ In our empirical analysis, we control for weak enforcement institutions by using the Difference-in-Difference method. In our sample the external shocks are the new labor laws; enforcement institutions did not change over the period.

${ }^{18}$ As already mentioned, in Indonesia there is a strong complementarity between labor NGOs' activities and labor unions. Some large trade unions regard labor NGOs as useful sources of technical and other kinds of assistance (McKay,
} 
Consistent with our sensitive sector hypothesis, the main Indonesian sectors targeted were textiles, footwear and apparel. APHEDA, for several years, have donated to labor unions in Bandung, where much of the workforce is employed in the footwear, clothing, and textiles industries. ACILs in 2005 assigned USD 90,000 for work related to local garment and textile unions. Novib supports the Clean Clothes Campaigns (CCC), a network organization that also supports workers, trade unions and NGOs in producer countries.

To identify the mechanism of interest, recall that we need three data dimensions: a time dimension to control for the introduction of labor unions; a sectoral dimension to control for the visibility premium; and a regional dimension to control for the presence of local NGOs in Indonesia.

\subsection{Data summary}

The dataset used for this analysis is derived from the Indonesian annual manufacturing survey collected and compiled by the Indonesian government's statistical agency BPS (Badan Pusat Statistik). BPS submits an annual questionnaire to all registered manufacturing establishments with 20 or more employees. The data cover the period before and after the 2000 Trade Union Act. The number of observations is around 20,000 firms per year. As already mentioned, we restrict our analysis to domestic firms (around 18,000). We have information on employees (wages) and the firms (industry, region, size, ownership, etc.). We rely also on a detailed database of Indonesian NGOs, publicly available on the website of SMERU, an Indonesian non-profit organization, for information on the regional presence of local NGOs specialized in labor issues.

Table 1, Column (1) shows the mean of real wages, in Rupiahs, for the manufacturing sector for 1991-1996 and 2004-2005. We define the average wage as the total wages for production workers at firm level, divided by the number of production workers. Following Harrison and Scorse (2010), we focus on production workers' wages, which we use as a proxy for unskilled workers.

We consider the period 1991-1996, before the Trade Union Act (2000), rather than the period 2005-2006. We focus on these years because the 1997 financial crisis and the fall of the Suharto Regime in 1998, makes analysis of post 1996 years problematic (Harrison \& Scorse, 2010). The Activists also emphasize the "synergy" and "symbiosis" between trade unions and NGOs Ford (2005). 
economic situation pre-crisis was re-established just after 2002 (Rahayu \& Sumarto, 2003).

Table 1 shows mean wages, profit-per-employee and number of workers (unskilled and skilled) in the period analyzed. Rows (1) and (2) in Table 2 report the average wage in provinces with no labor NGOs - our control group, and in provinces with labor NGOs - our treatment group. The t-test results reported in row (3) in Table 2 shows that the difference in mean wages between provinces with and without labor NGOs is not statistically significant. Hence, there is no risk of identification error.

To summarize, the trends presented in Table 2 indicate no difference in wages between the treatment and control groups before the 2000 labor law. This suggest that during the Suharto regime the wages paid by domestic firms were the same.

\subsection{Empirical Strategy}

\subsubsection{Wage equation}

First we estimate a simple wage equation inspired by the theoretical model in order to measure the bargaining power of workers in domestic firms.

Equation (2.3) leads to the following estimated wage equation:

$$
\ln w_{i j r t}=\beta_{0}+\beta_{1} \frac{\pi_{i j r t}}{n_{i j r t}}+\beta_{2} T F A_{i}+\eta_{t}+\epsilon_{i j r t}
$$

In this equation $l n w_{i j r t}$ is the $\log$ of the average wage in firm $i$, in sector $j$, in province $r$ and in period $t ; \pi_{i j r t}$ is the profit of the firm $i$, in sector $j$, in province $r$ and in period $t ; n_{i j r t}$ is the number of the firm's employees; $T F A$ is a sector dummy with $T F A=1$ if the firm is operating in the textile, footwear or apparel sector and 0 otherwise; $\eta_{t}$ is a year fixed effect. We proxy the visibility premium $(a \geq 0)$ by the sector dummy variable $T F A$. The evidence provided above on Northern donations to labor unions operating in the textile, footwear, and apparel sectors in the period under study, are the foundation for our assumption that $\alpha$, the visibility parameter, is 0 outside the garment sector. ${ }^{19}$ The parameter $\beta_{1}$ indicates the bargaining power of workers.

\footnotetext{
${ }^{19}$ Obviously, outside funding depends on the economic interest of donors in the North. The North targets sectors with significant import penetration and competing with domestic producers in industrialized countries. Therefore, we cannot exclude that, in the future, donations might target other sectors (than garments, textiles and footwear) in Indonesia as
} 
Following an approach similar to Martins (2004), we proxy for rents using "gross profits" 20 (i.e. profits before subtracting the wage bill). This avoids bias due to firms that share more rents having lower net profits (Martins, 2004).

Our initial results, presented in Table 3, Column (1), are obtained using an unbalanced panel regression. We include year fixed effects in the regression. ${ }^{21}$ Table 3 presents the results for gross profits, indicating a positive and significant coefficient. This first result suggests that rent sharing is a factor in the Indonesian labor market. The sector dummy, TFA, is positive but not significant.

\subsubsection{Instrumental Variable}

It is necessary to consider the simultaneity between profits and wages in estimating equation (3.1), where the equilibrium wage is determined by the level of profit-per-employee. Indeed, profits and wages are determined simultaneously. We use an instrumental variable to deal with endogeneity.

This instrumental variable used is a component of the firm's revenue, related to financial investments, participation in other firms, and non-operational activities. Our identification assumption follows the approach used by Martins \& Esteves (2007). Those components do not affect wages directly, but they are correlated with profits. The basic idea is that bargaining over wages is generally related to profits from the firm's mainstream activities, e.g. sales of garments for firms in the garment industry (Martins \& Esteves, 2007). If firm profits increase due to activities unrelated to the production of garments, the unions will typically be less likely to bargain over those profits (Martins \& Esteves, 2007). Our identification strategy is motivated also by the lack of transparency and information sharing between workers and employers in Indonesia, on the financial status of companies. The ILO Survey on Collective Bargaining in Indonesia (2006) states that: "Unions would like to have informations on the financial status of companies to assist them in setting attainable targets during collective bargaining".

Table 3, Column (2) presents the results of the 2SLS method, for our instrumental variable. We start by investigating the strength of the instrument in the first-stage equation, as measured by the values of the t-test of the coefficient of the instrumental variable: the coefficient is highly significant. For the main equation, we find that the coefficient is no longer significant.

\footnotetext{
well as in other DCs where competition from low standards countries threatens domestic producers in the North.

${ }^{20}$ The results do not change even if we consider net profit.

${ }^{21}$ We use the robust/cluster feature of STATA at firm level to have robust errors.
} 
These findings show that traditional rent sharing is not an important feature of the Indonesian labor market. Therefore, the evidence of rent sharing presented in the simple model, which does not consider the endogeneity of profits, could be misleading. The higher wages paid to employees in more profitable firms are artificially driven by the simultaneous determination of profits and wages (Martins \& Esteves, 2007). This result is in line with previous papers on rent-sharing in DCs (Martins \& Esteves, 2007; Bigsten et al., 2003). This absence of rent-sharing is explained by the weakness of labor market institutions in Indonesia, which is consistent with our line of reasoning. Indeed, both before and after the Suharto regime, Indonesians institutions were not strong; there continue to be violations of unions' rights. Also, the informal sector in Indonesia accounts for the majority of employment.

\subsubsection{The role of the 2000 Trade Union Act}

The previous section provides no empirical evidence of traditional rent-sharing in Indonesia. However, in the period examined there was an external shock. During the Suharto regime, independent labor unions were banned, but the Trade Union Act of 2000 guaranteed the right to organize and allowed groups of 10 or more workers to form a union. We now investigate whether the huge increase in the number of labor unions in the seven years since the new regulation has had a visible impact. We want to investigate whether the Trade Union Act of 2000 increased the bargaining power of workers. The model above stresses the role of NGOs and we expect that the presence of a labor union in a firm is not sufficient, based on the lack of a collective bargaining background among labor unions. We interact the variable profit-per-employee with a time dummy $T . T$ is equal to 0 for the period before the Trade Union Act of 2000 and 1 for the period after the law was passed.

The wage equation estimated is as follows:

$$
\begin{aligned}
& l n w_{i j r t}=\alpha+\beta_{1} \frac{\pi_{i j r t}}{n_{i j r t}}+\beta_{2} \frac{\pi_{i j r t}}{n_{i j r t}} T+ \\
& \beta_{3} T+\beta_{4} T F A_{i}+\beta_{5} X_{i r t}+\eta_{t}+\epsilon_{i j r t}
\end{aligned}
$$

Table 4, Column (1) shows the results. The coefficient of the interaction term is positive but not significant. This indicates that the 2000 Trade Union Act did not affect the "traditional" bargaining 
power of workers. This result supports our argument of limited negotiating knowledge among labor unions, but also lack of accountability with respect to union members. In the following section we investigate the absence of a negotiation culture; in section 3.3.5 we analyze the lack of accountability.

\subsubsection{The complementarity between labor union and local labor NGOs}

As mentioned above, there is strong complementarity between labor unions and local labor NGOs. Labor unions in Indonesia are relatively new and inexperienced. Collective bargaining was banned and the last period of the Suharto regime was characterized by radical movements and violent demonstrations. After the fall of Suharto and authorization of independent labor unions in 2000, the role of local labor NGOs was to rebuild negotiating capacity. Since then, labor NGOs have developed alliances with labor unions at province level and have supported small, firm level labor unions (Ford 2009). They provide technical and legal assistance to workers, and inform them about domestic labor laws and workers' rights. Therefore, the presence of local labor NGOs might be affecting the role of labor unions in the firm, due to this complementarity.

Important for our estimation strategy, in Indonesia local labor NGOs are not present in every province. ${ }^{22}$ We use a difference-in-difference approach to investigate the role of labor NGOs after the passing of the labor laws (Trade Union Act 2000) in a country with no experience or background in negotiation. We consider the difference in wages, between provinces with local labor NGOs and provinces with no local labor NGOs, for the period before and after the Trade Union Act of 2000. We construct a variable interacting the time dummy $T$ with the province dummy $N G O$, where $N G O=1$ for provinces with labor NGOs and $N G O=0$ for provinces with no labor NGOs.

The wage equation estimated is the following:

$l n w_{i j r t}=\alpha+\beta_{1} \frac{\pi_{i j r t}}{n_{i j r t}}+\beta_{2} \frac{\pi_{i j r t}}{n_{i j r t}} T+\beta_{3} T+\beta_{4} T F A_{i}+\beta_{5} X_{i r t}+\beta_{6} N G O_{r t}+\beta_{7} T * N G O_{r t}+\eta_{t}+\eta_{j}+\epsilon_{i j r t}$

\footnotetext{
${ }^{22}$ We observe the location of labor NGOs in Indonesia in a dataset of Indonesian NGOs constructed by SMERU, a non-profit research organization located in Indonesia. The provinces with local labor NGOs are: Nanggroe Aceh Darussalam, Sumatera Utara, Riau, DKI Jakarta, Jawa Timur I, Nusa Tenggara Barat, Sulawesi Tenggara.
} 
Table 4, Column (2) presents the results, with Treatment defined as firms located in a province with labor NGOs. The dependent variable, as before, is the average wage. Column (2) reports the coefficient estimates when we include the export dummy, the minimum wage, and other controls, at firm and province levels (e.g. firm size, number of skilled workers). The coefficient of the Treatment group is positive and highly significant. This result shows that the complementarity between labor NGOs and labor unions has a strong and positive impact on wage. The role of labor NGOs in rebuilding negotiating capacity has been effective. Note that we control for exporting since this might affect the decisions of the firms to pay higher wages due to reputation effects in provinces with outside pressure from NGOs. The export dummy is positive and highly significant. This result is in line with the analysis of Harrison \& Scorse (2010).

\subsubsection{The visibility premium of labor unions}

In the previous section, we analyzed the impact of labor NGOs on the outcome in a country with no individual experience in negotiation. The external funding implies a distortion: higher visibility of the labor union (i.e. the number of members employed in the formal sector) rather than focus on higher wages for workers. Only certain sectors are targeted by Northern donations. Therefore advantage of visibility is confined to these sectors. Our theoretical findings show that, labor unions working with sensitive sectors have contradicting objectives based on their financing constraints: to increase their visibility (i.e. the number of members employed in the formal sector) as well as achieve higher wages. In the specific case of Indonesia, the sectors targeted by Northern donations are textiles, garments and footwear: visibility of the labor union carries a premium.

We next investigate whether the financing constraint (the quest for visibility) of the labor unions translates into higher or lower wages when the presence of NGOs helped to rebuild the negotiating capacity of the labor unions. Our model shows two opposite effects: the positive impact of labor NGOs on wages, and the negative impact of the visibility premium of labor unions. We empirically test this hypothesis of a reduced outcome on wage in province with labor NGOs and in sector with visibility. We use a Difference-in-Difference-in-Difference method, in order to take account of the external shock (before and after the Trade Union Act 2000), the role of the complementarity between labor NGOs and labor unions (provinces with/without labor NGOs) and the visibility premium (textile versus other sectors). 
The equation estimated is the following:

$$
\begin{aligned}
\ln w_{i j r t}= & \alpha+\beta_{1} \frac{\pi_{i j r t}}{n_{i j r t}}+\beta_{2} \frac{\pi_{i j r t}}{n_{i j r t}} T+ \\
& \beta_{3} T+\beta_{4} N G O_{r t}+\beta_{5} T * N G O_{r t}+\beta_{6} T * N G O_{r t} * T F A_{i}+ \\
& \beta_{7} T * T F A_{i}+\beta_{8} T F A_{i} * N G O_{r t}+\beta_{9} T F A+\beta_{1} 0 X_{i r t}+\eta_{t}+\eta_{j}+\epsilon_{i j r t}
\end{aligned}
$$

Table 4, Column (3) presents the results. The coefficient of the interaction term variable $T * T F A *$ $N G O$ is negative and highly significant. This suggests that in sectors where the visibility of labor unions can be rewarded, wages increase less in presence of NGOs.

In all the estimations we include a year dummy to control for any aggregate shocks in years 1991-1996 and 2004-2005. We also include a sector dummy to control for any sector specific shocks. After controlling for sector and year fixed effect, the results do not change.

\subsubsection{Robustness Checks}

The dynamic economic and social environment of Jakarta (the capital of Indonesia) might be driving our main results. Table 5, Column (1) presents a first robustness check where we run the main regression as in equation (3.4) but exclude the province of the capital. The coefficient of our treatment variable, $N G O * T$, is positive and strongly significant. The coefficient of $N G O * T *$ $T F A$ is higher and still negative and significant.

A second potential issue is the presence of a large number of NGOs in a province, working on different problems, might create a specific environment that affects our results. We restrict the analysis to NGOs specialized in labor rights issues and Table 5, Column (3) control for the number of NGOs in each province. The results are mainly unchanged.

A third concern is with the indirect effect of the presence of foreign firms, on individual wage, at firm level, in the domestic sector. To address this, Column (3) also includes a variable, spillover, which measures the share of the foreign firms in the total value of production per province per year. The parameter of this variable is positive and significant, but the coefficients of $N G O * T * T F A$ and $N G O * T$ are unaffected.

Last, we add a dummy variable, highwage, which is equal to 1 if firms pay over the minimum 
wage, which could bias our results. The coefficient of this dummy variable (Column (3)) is positive and significant, while the sign and significance of our main variables of interest do not change.

We want also to ascertain that the mechanisms we have modeled are not present in sectors where visibility is not rewarded. To do this, we perform an additional robustness check in the form of an exercise replacing the TFA dummy with a dummy variable for other sectors. Table 7 presents the same regression as in equation (3.4). ${ }^{23}$ Table 6, Column (2) shows the coefficients of the interaction term $T * N G O *$ sector (our treatment in the difference-in-difference-in-difference estimation) generally are not significant. ${ }^{24}$ The only positive and significant coefficient is for the non-metallics sector. However, it concerns only domestic firms that do not export and thus cannot be related to some assistance from the North, to local labor unions. Overall, the results in Table 6, Column (2) suggest that the unexplained component of the wage reduction after the Trade Union Act of 2000 is restricted to plants in TFA sectors. This is the sector targeted by Northern donations in these years and thus the sector where the visibility of the labor unions is rewarded. In contrast, in Table 6, Column (1), the coefficient of our treatment in a difference-in-difference estimation, $T * N G O$, is always positive and significant. This result confirms that the presence of labor NGOs has a strong and positive effect on wages.

\subsection{Employment}

We have shown that the complementarity between labor unions and labor NGOs, and the constraint of outside funding of labor unions, affect wage in domestic manufacturing firms. The outcome on wages of the presence of NGOs is lower in sectors where labor union visibility is important because these unions rely on Northern NGO donations. This result might depend on outside pressure from the North on local labor unions to increase workplace/labor standards on top of wages, i.e. compensate wage differentials. However, on the one hand, donations to NGOs or other institutions usually are not audited or monitored. On the other hand, this outcome might depend on lack of accountability on the part of the labor unions with respect to their members. Labor unions might have a greater incentive to increase their visibility in order to access (more) external funding.

\footnotetext{
${ }^{23}$ Harrison and Scorse (2010) perform the same exercise.

${ }^{24}$ For the chemicals and printing sectors, the sign is negative and significant, but if we exclude the province of Jakarta, the coefficient is no longer significant. This suggests that the results related to these sectors are driven by some outliers in the province of Jakarta.
} 
Following Harrison and Scorse (2008), in Table 7 we replace the log of the production worker's wage with the log of production worker employment as the dependent variable. The coefficient of $T * N G O$ is positive but not significant. This suggests that the role of labor NGOs does not imply reduced employment. However, in Table 7 the coefficients of $T * N G O * T F A$ are robust and positive. This result suggests a positive impact on employment in sectors where labor unions achieve visibility, and in provinces with labor NGOs. This is in line with our theoretical predictions. The outside funding from the North implies a distortion in labor unions objectives of increasing their visibility (i.e. number of members employed in formal sector) taking precedence over achieving higher wages. The resulting reduction in wages corresponds to an employment increase, however, a result that suggests the existence of peculiarities in labor market institutions in DCs.

\section{Conclusion}

In the present paper we develop a bargaining model to study the interaction between the visibility premium, bargaining power, and outside option of workers, in the determination of individual wages in developing countries. With poor workers, labor unions have to rely on financing from NGOs in the North, and whether or not they receive financial aid depends, to a large extent, on labor union visibility. At the same time, labor movement is characterized by complementarity between labor unions and local NGOs working on labor issues. The argument is that local labor NGOs affect the outside option of workers by providing information on labor rights. Indeed, several developing countries have just recently experienced labor unions authorization. Therefore, there is often a lack of collective bargaining experience among labor unions. Local labor NGOs provide technical and legal assistance, and information on domestic labor laws and workers' rights. Their presence will change thus the outcome of collective bargaining.

Our theoretical findings highlight two contradictory effects: the positive impact of labor NGOs on wages, and the negative impact of the visibility premium of labor unions. The intuition behind this second result is that local labor unions have contradictory objectives when working in "sensitive" sectors: increasing their visibility and achieving their traditional objective of higher worker wages.

We empirically tested this hypothesis of a lower impact on wage in provinces with labor NGOs 
and in sectors with visibility. Indonesia is an ideal case because an important labor law, the Trade Union Act, was passed in 2000 and authorized independent labor unions following 30 years of authoritarian rule. We used data on the Indonesian manufacturing industry covering the period before and after the labor law. First, we estimated a simple wage equation derived from the theoretical model in order to analyze the bargaining power of workers. We found no evidence of the traditional bargaining power of workers. Weak labor institutions and the high rate of informal employment in Indonesia might explain this result. We then investigated whether the Trade Union Act increased workers' bargaining power by using a simple difference methodology. We interacted the profit-per-employees variable with a time dummy for the periods before and after the law. Our results suggest that the Trade Union Act did not affect the outcome on wages. This could be explained by weak enforcement institutions in Indonesia, lack of a collective bargaining background and lack of accountability of labor unions.

To investigate the complementarity between labor NGOs and labor unions, we used a Differencein-Difference method. We studied the difference in wages between provinces with labor NGOs (the treatment group) and provinces with no labor NGOs (the control group), before and after the labor laws (Trade Union Act 2000). We found that the presence of NGOs has a positive impact on wages. Therefore, this complementarity between labor unions and labor NGOs benefits workers in a country with no individual experience of negotiation.

External funding of labor unions was shown to distort their objective. We used a differencein-difference-in-difference method in order to study the outcome on wages in provinces with labor NGOs, and in sectors where the visibility of labor unions earns a premium. As already mentioned, the main sectors targeted by Northern donations in the years 2004 and 2005 were textiles, footwear and apparel (TFA). We analyzed the difference between the period before and after the Trade Union Act of 2000, in provinces with labor NGOs with respect to provinces without labor NGOs, and in TFA sector (i.e. sensitive sectors) with respect to other sectors. The results suggest that in sectors where the visibility of labor unions earns a premium (sensitive sectors), the outcome on wages of the presence of NGOs is lower. The intuition is that the presence of NGOs improves the bargaining capacity of labor unions. However, the external funding implies a distortion in labor union objectives to increase their visibility (i.e. the number of members employed in the formal sector) over achieving higher wages. Labor unions that receive outside funding are accountable to 
their donors.

This work opens up many directions for research because it highlights the complexity of relations on the labor markets of developing countries that are trying progressively to reorient attitudes towards more worker-friendly institutions. For instance, there could be some form of competition among the labor unions in the South, and also between labor unions and local NGOs. The outside funding mechanism and its impact on labor institutions in developing countries is an important issue that requires further research. Another important issue concerns the outside options of workers and relative wages in the formal and informal sectors, taking account of the compensations afforded by the informal sector for harsh working conditions. The first issue is not necessarily relevant to Indonesia given the good complementarity between labor unions and labor NGOs in this initial phase of changes in the labor market. The second issue does apply to Indonesia but unfortunately is rarely empirically documented. 


\section{References}

Aldashev, G. \& Verdier, T. (2009). When ngos go global: Competition on international markets for development donations. Journal of International Economics, 79(2), 198-210.

Antras, P. \& Helpman, E. (2004). Global sourcing. Journal of Political Economy, 112 n.3, 552580.

Bigsten, A., Collier, P., Dercon, S., Fafchamps, M., Gunning, J. W., Oduro, A., Oostendorp, R., Pattillo, C., Söderbom, M., Teal, F., \& Zeufack, A. (2003). Risk sharing in labour markets. Tinbergen Institute Discussion Papers 03-077/2, Tinbergen Institute.

Boeri, T., Helppie, B., \& Macis, M. (2008). Labor regulations in developing countries : a review of the evidence and directions for future research. sp discussion paper N. 0833, Social Protection and Labor, The World Bank.

Botz, D. L. (2001). Made in Indonesia. South End Press, Cambridge, Massachusetts.

Brown, A. (2004). Labour, Politics and the State in Industriaizing Thailand. London:RoutledgeCurzon.

Caraway, T. (2004). Protective repression, international pressure, and institutional design: Explaining labor reform in indonesia. Studies in Comparative International Development (SCID), Volume 39, Number 3, 28-48.

Crinis, V. (2008). Malaysia: Women, labour activism and unions. in k. broadbent and m. ford,. Women and Labour Organizing in Asia: Diversity, Autonomy and Activism, London:Routledge.

Ford, M. (2005). Accountable to whom? trade unions, labour ngos and the question of accountability in indonesia. Working Paper Series, $n .81$.

Ford, M. (2009). Workers and Intellectuals. NGOs, Trade Unions and the Indonesian Labour Movement. Southeast Asia Publications Series.

Harrison, A. \& Scorse, J. (2010). Multinationals and anti-sweatshop activism. American Economic Review, 100:1, 247-273. 
Julia, L. \& Putranto, P. (2006). Ilo survey on collective bargaining in indonesia. Technical report, ILO.

Martins, P. (2004). Rent sharing before and after wage bill. IZA Discussion Paper 1376.

Martins, P. \& Esteves, L. A. (2007). Is there rent sharing in developing countries? matched-panel evidence from brazil. Working Papers 0060, Universidade Federal do Paraná, Department of Economics, IZA.

McKay, S. (2006). The squeaky wheel's dilemma: New forms of labor organizing in the philippines. Labour Studies Journal, 30 (4), 41-63.

Rahayu, S. \& Sumarto, S. (2003). The practice of industrial relations in indonesia. The SMERU Research Institute. 
Table 1: Mean of wage, profit-per-employee, number of production workers and number of skill workers for years 1991-2005

\begin{tabular}{lrrrr}
\hline year & wage & profit-per-employee & nbworker & nbskill \\
\hline 1991 & $5,938.20$ & 477.51 & 153.50 & 23.26 \\
1992 & $13,237.26$ & $1,147.51$ & 157.17 & 25.20 \\
1993 & $8,353.82$ & 646.74 & 160.32 & 23.40 \\
1994 & $8,026.54$ & 686.72 & 164.06 & 25.63 \\
1995 & $9,574.06$ & 785.47 & 159.51 & 23.85 \\
1996 & $15,498.04$ & $1,299.08$ & 149.46 & 23.42 \\
2004 & $59,013.42$ & $5,511.16$ & 166.67 & 26.00 \\
2005 & $60,659.13$ & $5,785.65$ & 159.68 & 24.24 \\
\hline Total & $22,994.80$ & $2,084.51$ & 158.69 & 24.36 \\
\hline All values are in real Rupiahs & & &
\end{tabular}


Table 2: Comparison of Treatment Groups relative to Controls Prior to Treatment (1991-1996)

\begin{tabular}{lrrrrrr}
\hline NGO & wage & profit-per-employee & nbworker & nbskill & EXP & TFA \\
\hline (1) Control & $10,040.83$ & 848.66 & 166.99 & 25.58 & 0.16 & 0.25 \\
(2) Treatment & $10,754.10$ & 877.70 & 144.43 & 22.20 & 0.12 & 0.21 \\
& & & & & & \\
(3) t-test diff & -1.77 & -1.01 & $5.50^{* * *}$ & $4.63^{* * *}$ & $20.87^{* * *}$ & $17.01^{* * *}$ \\
\hline Total & $10,351.72$ & 861.32 & 157.16 & 24.11 & 157071 & 157071 \\
\hline \hline
\end{tabular}

$\mathrm{A} *$ indicates the difference in means is statistically significant at $0.05 ; \mathrm{a} * *$ indicates the difference in means is statistically significant at $0.01 ; \mathrm{a} * * *$ indicates the difference in means is statistically significant at 0.001 . All values are in real Rupiahs 
Table 3: Panel regression for year 1991-2005; IV Estimates for year 1991-2005

Dependent variable: $\log$ plant average unskilled wage

\begin{tabular}{lrr}
\hline \hline & Panel & IV Estimates \\
& $(1)$ & $(2)$ \\
& Coef./se & Coef./se \\
\hline profit-per-employee & $0.003^{*}$ & 0.003 \\
& $(0.001)$ & $(0.002)$ \\
TFA & 0.019 & 0.019 \\
& $(0.02)$ & $(0.02)$ \\
minwage & $0.004^{* * *}$ & $0.004^{* * *}$ \\
& $(0.00)$ & $(0.00)$ \\
nbworker & & $-0.06^{* * *}$ \\
& & $(0.00)$ \\
\hline r2 & 0.692 & 0.693 \\
$\mathrm{~N}$ & 142093 & 134644 \\
\hline \hline Controls & No & Yes \\
\hline Year fixed effect & Yes & Yes \\
\hline \hline Sector fixed effect & Yes & Yes \\
\hline \hline other income & & Yes \\
& & Yes \\
\hline \hline Year fixed effect & Yes & Yes \\
\hline Sector fixed effect & Y.000885*** \\
\hline \hline
\end{tabular}

Standard error in parentheses, with * significance at 0.10, ** significance at 0.05 and $* * *$ significance at 0.01. Constant term included in all specifications but not reported here. Notes: Instrumental variable: income received from non-operational activity. Note: cluster at firm level. Control for number of skilled workers at plant level and for export status. 
Table 4: Simple Difference; Difference in Difference; Difference in Difference in Difference

Dep var: Average unskilled wage

\begin{tabular}{|c|c|c|c|}
\hline & $\begin{array}{r}\mathrm{D} \\
(1)\end{array}$ & $\begin{array}{r}\text { DD } \\
(2)\end{array}$ & $\begin{array}{r}\text { DDD } \\
\text { (3) }\end{array}$ \\
\hline \multirow[t]{2}{*}{$\mathrm{T}^{*}$ profit-per-employee } & 0.007 & 0.007 & 0.007 \\
\hline & $(0.00)$ & $(0.00)$ & $(0.00)$ \\
\hline \multirow[t]{2}{*}{ profit-per-employee } & -0.004 & -0.004 & -0.004 \\
\hline & $(0.00)$ & $(0.00)$ & $(0.00)$ \\
\hline \multirow[t]{2}{*}{ nbworker } & $-0.05 * * *$ & $-0.05 * * *$ & $-0.05 * * *$ \\
\hline & $(0.00)$ & $(0.00)$ & $(0.00)$ \\
\hline \multirow{2}{*}{ TFA } & $0.029 *$ & $0.043 * * *$ & \\
\hline & $(0.02)$ & $(0.02)$ & \\
\hline \multirow[t]{2}{*}{ minwage } & $0.004 * * *$ & $0.005 * * *$ & $0.005 * * *$ \\
\hline & $(0.00)$ & $(0.00)$ & $(0.00)$ \\
\hline \multirow[t]{2}{*}{$\mathrm{T}$} & $2.071 * * *$ & $1.990 * * *$ & $1.976 * * *$ \\
\hline & $(0.02)$ & $(0.03)$ & $(0.03)$ \\
\hline \multirow[t]{2}{*}{ EXP } & $0.024 * * *$ & $0.023 * *$ & $0.024 * *$ \\
\hline & $(0.01)$ & $(0.01)$ & $(0.01)$ \\
\hline \multirow[t]{2}{*}{ T*NGO } & & $0.165^{* * *}$ & $0.184 * * *$ \\
\hline & & $(0.03)$ & $(0.03)$ \\
\hline \multirow[t]{2}{*}{ T*NGO*TFA } & & & $-0.087 * * *$ \\
\hline & & & $(0.03)$ \\
\hline \multirow[t]{2}{*}{ T*TFA } & & & $0.074 * * *$ \\
\hline & & & $(0.02)$ \\
\hline $\mathrm{r} 2$ & 0.681 & 0.681 & 0.681 \\
\hline $\mathrm{N}$ & 127917 & 127917 & 127917 \\
\hline Controls & Yes & Yes & Yes \\
\hline Year fixed effect & Yes & Yes & Yes \\
\hline Sector fixed effect & Yes & Yes & Yes \\
\hline \multicolumn{4}{|c|}{$\begin{array}{l}\text { Standard error in parentheses, with * significance at } 0.10, * * \text { significance } \\
\text { at } 0.05 \text { and } * * * \text { significance at } 0.01 \text {. Constant term included in all spec- } \\
\text { ifications but not reported here. Notes: Instrumental variable: income } \\
\text { received from non-operational activity. Note: cluster at firm level. Con- } \\
\text { trol for: number of skilled workers at plant level; sign of the difference } \\
\text { between provincial and average of minimum wage at national level; and } \\
\text { interaction between presence of NGO and provincial minimum wage. }\end{array}$} \\
\hline
\end{tabular}


Table 5:

Robustness Checks (1)

\begin{tabular}{|c|c|c|c|}
\hline & $\begin{array}{c}1 \\
\text { Coef./se }\end{array}$ & $\begin{array}{c}2 \\
\text { Coef./se }\end{array}$ & $\begin{array}{c}3 \\
\text { Coef./se }\end{array}$ \\
\hline $\mathrm{T}^{*}$ profit-per-employee & $\begin{array}{c}0.017 * * * \\
(0.01)\end{array}$ & $\begin{array}{l}0.008 \\
(0.01)\end{array}$ & $\begin{array}{l}0.009 \\
(0.01)\end{array}$ \\
\hline profit-per-employee & $\begin{array}{c}-0.011^{*} \\
(0.01)\end{array}$ & $\begin{array}{l}-0.004 \\
(0.01)\end{array}$ & $\begin{array}{l}-0.005 \\
(0.01)\end{array}$ \\
\hline T*NGO & $\begin{array}{c}0.188^{* * *} * \\
(0.03)\end{array}$ & $\begin{array}{c}0.153 * * * \\
(0.03)\end{array}$ & $\begin{array}{c}0.180^{* * *} \\
(0.03)\end{array}$ \\
\hline $\mathrm{T}$ & $\begin{array}{c}1.978 * * * \\
(0.04)\end{array}$ & $\begin{array}{c}2.064 * * * \\
(0.03)\end{array}$ & $\begin{array}{c}1.981 * * * \\
(0.03)\end{array}$ \\
\hline T*NGO*TFA & $\begin{array}{c}-0.117 * * * \\
(0.04)\end{array}$ & $\begin{array}{c}-0.097 * * * \\
(0.03)\end{array}$ & $\begin{array}{c}-0.090 * * * \\
(0.03)\end{array}$ \\
\hline $\mathrm{T}^{*} \mathrm{TFA}$ & $\begin{array}{c}0.079 * * * \\
(0.02)\end{array}$ & $\begin{array}{c}0.079 * * * \\
(0.02)\end{array}$ & $\begin{array}{c}0.076 * * * \\
(0.02)\end{array}$ \\
\hline nbworker & $\begin{array}{c}-0.060 * * * \\
(0.01)\end{array}$ & $\begin{array}{c}-0.059 * * * \\
(0.01)\end{array}$ & $\begin{array}{c}-0.058^{* * * *} \\
(0.01)\end{array}$ \\
\hline minwage & $\begin{array}{c}0.005^{* * *} \\
(0.00)\end{array}$ & $\begin{array}{c}0.003 * * * \\
(0.00)\end{array}$ & $\begin{array}{c}0.006^{* * * *} \\
(0.00)\end{array}$ \\
\hline EXP & $\begin{array}{c}0.021 * * \\
(0.01)\end{array}$ & $\begin{array}{c}0.029 * * * \\
(0.01)\end{array}$ & $\begin{array}{c}0.024 * * * \\
(0.01)\end{array}$ \\
\hline spillover & & $\begin{array}{c}0.083 * * * \\
(0.03)\end{array}$ & \\
\hline nbNGO & & $\begin{array}{c}0.0003 \\
(0.00)\end{array}$ & \\
\hline highwage & & & $\begin{array}{c}5.901 * * * \\
(0.63)\end{array}$ \\
\hline r2 & 0.673 & 0.685 & 0.688 \\
\hline $\mathrm{N}$ & 112826 & 125200 & 127917 \\
\hline Year fixed effect & Yes & Yes & Yes \\
\hline Sector fixed effect & Yes & Yes & Yes \\
\hline
\end{tabular}

Standard error in parentheses, with * significance at $0.10, * *$ significance at 0.05 and *** significance at 0.01 . Constant term included in all specifications but not reported here. Notes: Instrumental variable: income received from non-operational activity. Note: cluster at firm level. Control for: number of skilled workers at plant level; sign of the difference between provincial and average of minimum wage at national level; interaction between presence of NGO and provincial minimum wage; and regional population in Column (2). 
Table 6:

\begin{tabular}{lrr}
\multicolumn{3}{c}{ Robustness Checks (2) } \\
\hline \hline & TNGO & TNGOsector \\
& Coef./se & Coef./se \\
\hline Electronic & $0.16^{* * *}$ & -0.052 \\
Furniture & $(0.02)$ & $(0.11)$ \\
& $0.16^{* * *}$ & -0.02 \\
Food & $(0.03)$ & $(0.04)$ \\
& $0.17^{* * *}$ & -0.02 \\
Paper & $(0.03)$ & $(0.02)$ \\
& $0.15^{* * *}$ & -0.07 \\
Printing & $(0.03)$ & $(0.07)$ \\
& $0.15^{* * *}$ & -0.03 \\
Petroleum & $(0.04)$ & $(0.09)$ \\
& $0.15^{* * *}$ & -0.09 \\
Chemical & $(0.04)$ & $(0.29)$ \\
& $0.15^{* * *}$ & -0.12 \\
Non-metallic & $(0.03)$ & $(0.08)$ \\
& $0.12^{* * *}$ & $0.12^{* *}$ \\
Plastic & $(0.03)$ & $(0.05)$ \\
& $0.15^{* * *}$ & -0.06 \\
Metallic & $(0.03)$ & $(0.04)$ \\
& $0.15^{* * *}$ & 0.09 \\
Machinery & $(0.03)$ & $(0.16)$ \\
& $0.16^{* * *}$ & -0.11 \\
Other Manufacturing & $(0.03)$ & $(0.07)$ \\
& $0.16^{* * *}$ & -0.04 \\
& $(0.03)$ & $(0.05)$ \\
\hline \hline
\end{tabular}

Notes: Coefficients of chemicals and printing when we exclude the province of Jakarta. For non-metallic mineral product, see text. Note: cluster at firm level. Control for: number of skilled workers at plant level; sign of the difference between provincial and average of minimum wage at national level; and interaction between presence of NGO and provincial minimum wage. 
Table 7: Difference in Difference; Difference in Difference in Difference

Dep var: $\log$ production workers

\begin{tabular}{|c|c|c|}
\hline & $\begin{array}{r}\mathrm{DD} \\
(1)\end{array}$ & $\begin{array}{r}\text { DDD } \\
\text { (2) }\end{array}$ \\
\hline $\mathrm{T}^{*}$ profit-per-employee & $\begin{array}{c}-0.006 \\
(0.00)\end{array}$ & $\begin{array}{r}-0.006 \\
(0.00)\end{array}$ \\
\hline profit-per-employee & $\begin{array}{r}0.012^{* *} \\
(0.00)\end{array}$ & $\begin{array}{r}0.012 * * \\
(0.00)\end{array}$ \\
\hline T*NGO & $\begin{array}{r}0.043^{*} \\
(0.02)\end{array}$ & $\begin{array}{l}0.032 \\
(0.02)\end{array}$ \\
\hline $\mathrm{T}$ & $\begin{array}{r}0.051^{* *} \\
(0.02)\end{array}$ & $\begin{array}{r}0.060 * * \\
(0.02)\end{array}$ \\
\hline TFA & $\begin{array}{r}-0.098 * * * \\
(0.01)\end{array}$ & \\
\hline minwage & $\begin{array}{r}-0.0002 \\
(0.00)\end{array}$ & $\begin{array}{r}-0.0003 \\
(0.00)\end{array}$ \\
\hline EXP & $\begin{array}{r}0.129 * * * \\
(0.01)\end{array}$ & $\begin{array}{r}0.129 * * * \\
(0.01)\end{array}$ \\
\hline T*NGO*TFA & & $\begin{array}{r}0.053^{*} \\
(0.03)\end{array}$ \\
\hline $\mathrm{T}^{* \mathrm{TFA}}$ & & $\begin{array}{r}-0.117 * * * \\
(0.02)\end{array}$ \\
\hline $\mathrm{r} 2$ & 0.019 & 0.019 \\
\hline $\mathrm{N}$ & 128092 & 128092 \\
\hline Controls & Yes & Yes \\
\hline Year fixed effect & Yes & Yes \\
\hline Sector fixed effect & Yes & Yes \\
\hline \multicolumn{3}{|c|}{$\begin{array}{l}\text { Standard error in parentheses, with * significance at } 0.10 \text {, } \\
* * * \text { significance at } 0.05 \text { and *** significance at } 0.01 \text {. Con- } \\
\text { stant term included in all specifications but not reported } \\
\text { here. Notes: Instrumental variable: income received from } \\
\text { non-operational activity. Note: cluster at firm level. Control } \\
\text { for: number of skilled workers at plant level; sign of the dif- } \\
\text { ference between provincial and average of minimum wage } \\
\text { at national level; interaction between presence of NGO and } \\
\text { provincial minimum wage; and real wage at firm level. }\end{array}$} \\
\hline
\end{tabular}

